TURIZAM

Volume 18 , Issue 4

154-165 (2014)

\title{
Business Ethics of Tour Operators - The Case Study of TUI
}

\author{
Marija Šuleić, Aleksandra Dragin, Vanja Dragićević*
}

Received: June 2014 | Accepted: September 2014

\begin{abstract}
A large number of participants in tourism, both in offer and in demand, has conditioned the need for the creation ethical codices based on legislative regulations and moral principles. Among central figures in tourism, there are travel agencies and tour operators, the intermediaries between service providers and service users, in other words, passengers. The tour operators who are engaged in initiating tourism provide the services on foreign markets and tend to adapt their business to the laws and customs of the countries in which they run a business. TUI, as a leading European tour operator, which has even its representation in Serbia, can be a good example of the implementation of its business codes of ethics, but also adapting to the business customs being valid in the country in which TUI operates. Because of this, the aim of this work was to examine under what ethical standards TUI operates in Serbia in the domain of different stakeholders. The results of the research can be useful for different stakeholders.
\end{abstract}

Key words: TUI, business ethics, stakeholder, Serbia.

\section{Introduction}

Various authors emphasize different elements of business ethics (Lewis, I985; D’Amore, I993; Connock and Johns, I995; Dunfee, Black, I996; Malloy, Fennell, I998; Trevino and Nelson, I999; Stevens, 2OOI; Orme and Ashton, 2003; Ristić, 2004; Fennell and Malloy, 2007; Bogdanovic, 2008; Minciu, 2008; Dornier, Cothias, Loussaief, 2OII; Jovicic, Pivac and Dragin, 2OII; Miskovic 2OI2). Lewis defines business ethics as rules, standards, codes or principles, which provide guidelines for morally right behavior and truthfulness in specific situations (Lewis, I985, 38I). It is about fairness and decision what is right or wrong, about defining the practices and rules, which underpin responsible conduct between individuals and groups (Connock and Johns, I995). Ristic (2004) points out that the subject of business ethics is a cut which is formed by the blending of moral and economic aspects of business. Modern concept in managing business ethics is the concept of social responsibility of a company as one of the ways of ethical impact of the organization with the aim of

\footnotetext{
* University of Novi Sad Faculty of Sciences, Department of Geography, Tourism and Hotel Management, Trg Dositeja
} Obradovića 3, 21000 Novi Sad, Serbia, Corresponding author: marijasuleic@yahoo.com 
achieving public good, in other words, well-being of the society in general. Socially responsible business represents a duty of governance structure of a company towards the profit and interests of the society, which gives the society sustainability and development and which is under the influence of the activity and policy of the organization (Dragin, 2OII). The aim of this research was to examine under what ethical standards a tour operator do business in Serbia in the cooperation with different stakeholders, which has been also done on the example of TUI company.

The consideration and the analysis of the relationship of TUI towards its end-users tourists have been excluded, because they have to be the subject of a specific examination.

\section{Ethical codex of TUI}

TUI was founded in I968. To this day, it has expanded its sales network in I8 countries with over 3,5OO offices. There are I2O airplanes, IO cruisers and 285 hotels in TUI's ownership (TUI documentation). The TUI turnover in financial year 2OI2-2OI3 was I8,500,000,000 euros and the earnings in the same year were $762,000,000$ euros. Final annual salary was I87,000,000 euros after the deduction of amortization, interest and tax-fees. The Group has over 74,4OO employees. (http://www.tui-group.com/en/company/profile, http://de.statista. com/statistik/daten/studie/30079/umfrage/umsatz-der-tui-ag/)

TUI company has developed and implemented a model of organizational and economic activities based on three business domains: TUI as a company, franchises and intermediaries. TUI as a company has its branches: TUI Germany, TUI Austria, TUI Netherlands, and Thompson in Great Britain. The headquarters of TUI are in Hannover (Germany), although all branches have their own defined degree of independence. Franchises, as it is the case with Serbia or, for instance, with Romania, are under the control of the nearest branch. In the case of the Balkans, it is Austria. In order that franchises become partners of TUI, a trade is to be made, defined by the size of the market on which the agency operates. Intermediaries are the last in the range. They have the least rights, but also the least obligations. Intermediary agencies sell only TUI services to end-users and they are allowed to receive certain commission. This will be discussed in more details.

The aspects of business are defined by the standards of the company's brand and segmentation of available jobs. TUI standards are strictly defined by the contracts with which all branches, franchises and intermediaries must comply. There is a book of rules which starts from the point of how offices should look like, but also a book of rules about the basic values of the company, which will be considered through business ethics, in other words, ethical codex.

In Serbia, officially from 2009 (www.tui-reisecenter.rs), TUI has its own business code of ethics, published by the headquarters in Hannover (http://www.tui-group.com/ uuid/5a4a969abefi4cdoa9Oc04724dfob3e8). TUI in Serbia is an exclusive representative of TUI brand in ex-Yu countries, except Slovenia: Serbia, Croatia, Montenegro, Macedonia, Bosnia and Herzegovina and Albania. By obtaining a franchise, the right to the use of logo and owning brands of TUI is gained, but also the range of specific standards which must be met. What is characteristic is that TUI partners do not create the travel plans independently, but the act only as intermediaries. They are allowed to receive certain commission for a made trade and they are given the possibility to develop professionally with a small participation, or for free. Moreover, depending on the success of the representation, the participa- 
tion donated by TUI for the investment in marketing depends. By signing the contract, it is precisely defined what growth is expected from the recipient of a franchise and the ways of the offer presentation, technical and decorative solutions about the space arrangement, the ways and possibilities for advertising, work in systems, protection and keeping of the brand.

Considering the fact that TUI in Serbia is a representative of other German tourist brand, such as FTI, Neckermann, Thomas Cook, Vtours, in order to create conditions so as not to lose the franchise, it is predicted by the contract how much participation of the total trade must be made via TUI product (TUI documentation in Serbia, 2OI3), which is correct, considering the fact distributors of the franchise have permitted the service sales of the competition in their outlets. Franchisors have the right to visit franchisees even without a prior notification and the franchisees have the same right as well in relation to subagents. For obtaining a franchise, the bank guarantee is needed. One of the questions of business ethics being posed is that TUI Austria can hand over its logo for use to a legal entity (e.g. from Serbia) if they leave the bank guarantee without the consent of TUI in Serbia. This can be viewed as the infringement of the credibility of franchisors in Serbia. This creates the possibility of the reduction of business of the franchise holder, because a part of the market is given to the agencies which have submitted the bank guarantees. What more, in 2013 in Serbia, the openings of companies with headquarters in Germany are being noticed in Serbia and they do not have the licence in Serbia. These tour operators are, so-to-speak „out of control“ because they operate in their own way, not complying with the laws governing in Serbia. Like all countries in transition, the laws do not cover all domains of business in Serbia as well, which creates possibilities for various type of manipulation. Yet, the questions arise how it is possible that some foreign agency runs a business without the licence when the inspection controls are rigorous when checking the business activities of travel agencies and the conditions for obtaining the licence.

\section{The relationship of branches towards intermediaries (subagents and competition)}

„According to the policy of a company, the competition is a natural phenomenon which forces us to fight for the market in a correct way, with the respect of other participants on the market and adapting to a sustainable way of business activities“ (TUI documentation, 2OI3). Therefore, the obligations towards competitors and tourism market are in general:

- To responsibly perform its role as leaders, conscious of the impact which the company's attitude may have on the sector;

- To contribute to the protection and improvement of the reputation of the whole tourism sector;

- To make active cooperation with the companies from all sectors, regardless of their position and size;

- To compete in an ethical manner on the markets, with respect and avoid wrong ways to create a competitive advantage;

- To refrain from collecting information about our customers or competitors through unethical methods;

- To refrain from making public negative comments about our competitors;

- To act with good purpose and foster good relationships and mutual benefits in the sector, including even the competition (TUI documentation, 2OI2).

Each representative on his/her market has the right to the distribution of the TUI services to other legal entities, or agencies. The contract is concluded with these agencies, in other 
words, the contract on subagentura. Considering the fact that there is no prescribed ethical codex in Serbia by the responsible national and state authorities and the associations of travel agencies, many aspects of business activities have not been defined, which leaves room for different oversights and malversations. Some national travel agencies were deprived of the licence in previous years.

In order to avoid the same and other scandals, according to the subagent contract, the following applies:

- Impossibility of changing the price in relation to the ones published on websites and in the reservation systems;

- Obligatory possession of a shop-window and premises on the street or in the shopping centre;

- The protection of TUI brand;

- The prohibition of TUI's products to other travel agencies arbitrarily;

- Delivery of a blank bill of exchange and a letter of authorization.

The TUI franchise means that an agency in Belgrade can run its services, besides the market in Serbia, even in Macedonia, Montenegro, Bosnia and Herzegovina and Croatia.

Considering the fact that numerous agencies are involved in sales, various details are regulated by the contract on cooperation and by the annexes of contract as well. The agent service in TUI is obliged to train colleagues from other agencies for work in the systems Traffic and Iris Plus and to provide them with a necessary support in sales for them. All systems are in the German language. Therefore, the employees are required to be patient and ready to help when the help with codes and service description is needed. If the clients of subagents are not satisfied with the received service, all remarks and complaints must go to the agency where the service was bought. If an end-user decides to file a complaint directly to TUI, employees are obliged to direct him/her discreetly to the agent who had made the reservation. It is strictly prohibited in this case to switch the blame on the business agency which is TUI's partner.

If a subagent does not fulfil his/her obligations on time, the agent's service is obliged to warn him/her in writing about the payment of 30 days in advance. In case that he/she does not make the payment within 20 days before the travel, he/she is obliged to withdraw the bill of exchange, which is submitted on signing the contract.

On the other hand, a subagent is expected to deliver to end-users all the information from the system like the information about the categorization of the hotel, which is in this case TUI's and can be different in relation to the local categorization. Moreover, he/she is obliged to give the information if there is a building-site in the vicinity or if a part of the hotel is under reconstruction. The subagent is obliged to transfer all the given information to his/her clients in order to avoid their dissatisfaction with the received service.

During the cooperation, mutual trust must be built, as well as strong partnerships. If the agent's service notices mistakes in business activities, i.e. that the subagent does not fulfil the conditions for obtaining the contract, it is obliged to warn the subagent about the oversights.

If they are not removed, the agent's service is obliged to break the cooperation agreement. It is most strictly prohibited to increase the price. All TUI's arrangements must be sold at the same price anywhere in Europe.

Depending on the function which they have in TUI, employees are obliged to follow the competition and to analyze their actions. Each bad comment of the competition is prohibited. 
Any discounts for winning over the clients from the competition are not permitted, except with airplane tickets when the sales agent can reduce the earnings, because there is no fixed price as opposed to the arrangements. The cooperation with the service providers is mostly defined in contracts signed by TUI Germany. Each agent is obliged to keep the contract as a business secret and to present business partner in the best possible way. As opposed to some tour operators, especially when it comes to hotels in Greece, it is precisely defined by the contract that the hotel must not seek additional payment from the clients who are Serbian citizens. This problem has appeared as a consequence of the monopoly of national tour operators/agencies which sell their services at much higher price. Some require hoteliers to demand the difference in price if the guests of the hotel are Serbs. This problem was expressed especially in 2010 when clients reported themselves on the arrival in the hotel because additional payment was demanded from them at the reception desk. The problem was solved as one goes along and nobody made additional payment. In order to protect their clients, a clause has been introduced into the contract, stating that it is prohibited for hoteliers to seek any additional payment for the stay.

In order to maintain good business relationships, it is necessary for the service providers or other tour operators to forward the payments on time. If, for some reason, the payment cannot be made on time, it is necessary to notify the service provider or tour operators in writing about it in order to avoid disagreements or the loss of confidence.

With the conclusion of the contract on the cooperation with hotels, the number and the type of the rooms being taken in lease are precisely defined and, also, the way of the capacity lease.

If the allotment contract without the guarantee of filling is concluded, a tour operator is obliged to notify the hotel about the number of sold accommodation entities and to return unsold rooms to the hotel so that it could offer them to others. The cooperation contract precisely defines the deadline during which a tour operator is obliged to return the unsold capacity. The contracts on fixed lease are concluded before the beginning of the season and the tour operator insists most often on the contingents with the best rooms for the reason that all rooms be in the same part of the hotel. TUI, while concluding a contract, insists on the contingents with the best rooms for the reason that they occupy large capacities. With the hotels of higher categories, the clauses of exclusivity are frequently introduced according to

Which guests are received with welcome at the reception desk or they are provided with additional services to which the guests who have arrived via other tour operators do not have the right.

During the sale, sales agents, first of all, are obliged to promote hotels owned by TUI and, later, other hotel chains. As one of dilemmas of business ethics, the problem of a so-called reservation fee appears. Namely, by contracts, any change in the price with regard to the ones published on websites and in the reservation systems is strongly prohibited. Tour operators and travel agencies introduce reservation fees aiming at additional earnings. There is no breach of the contract in this way, but the question of business ethics arises. Should clients be charged for the interview with sales agents? Should clients pay for compensation because they use the services provided by a tour operator? This practice is applied even by some foreign tour operators doing business in Serbia. The research conducted by TUI in Serbia indicates that this causes great dissatisfaction in clients so that they are ready to pay for the same services via another agency (the documents of TUI, 2OII). This research made TUI change 
its decision about charging for the reservation fee, which, according to the TUI statistics, made even 400 passengers organize their travel during one year via the stated tour operator.

Insufficiently regulated business environment, as well as the transition of the economic and legal environment, has caused even unfair competition. With reference to the fact that this segment of business operations is not precisely defined by law, problems arise among foreign and national tour operators. This problem is best reflected by the example of the hotels in Greece. Namely, for their numerosity, our tourists are an important segment in the reception of Northern Greece, which national tour operators frequently misuse while concluding a contract with hotels. A certain clause is frequently inserted in the contract that the hotel will not receive guests from Serbia who come via foreign tour operators. National tour operators create a monopoly in this way and make a profit as a result of large margins. Foreign tour operators often come to know about this problem only after they deliver the guest list to a hotel. In order to prevent dissatisfaction of their clients, they are forced to give them better hotels in exchange, which directly influences the profitability of business operations. Huge losses occur in these cases for the representations of foreign tour operators and, at the same time, a considerable profit for national tour operators.

When the contracts on the cooperation with airline companies are reached, the charter flights and classes on scheduled flights are concluded. If charters are concluded, the deadline for payment, travel conditions and price is precisely defined. The attention is paid even to the flight schedule in order to avoid the situations in which passengers lose one day in departure or in return, thus leaving room for forming complaints. In some cases, the contract with charters is made even with other tour operators, especially in the conditions when there is not high season so that TUI takes on lease a certain percentage of seats while leaving one part to other tour operators. By the contract, the situation is often predicted that, in case that one of the lease-holders sells leased seats, he/she can take over so many seats from other lease-holders as they are ready to yield them up to him/her.

With the charter contracts, the weight of the luggage which a passengers brings with himself/themselves is also taken into account. There is a tendency to establish the standard that the passengers travelling via TUI can have $30 \mathrm{~kg}$ without charge. This rule has not been applied yet for all airlines.

TUI enters into the contract with airline companies on the sales of airplane tickets on regular flights. It sells airplane tickets via its reservation system and what is characteristic is that those classes often cannot be found in any other reservation system. Namely, the contract is concluded in order that TUI takes on lease the most acceptable classes on the flights of airline companies and they do not have the right to sell the same classes via other reservation systems. This question is disputable: on the one hand, it looks like a monopoly, and, on the other hand an exclusivity, because it is very important for each airline company to launch their airplane tickets via TUI due to the size and traffic volume.

The insurance companies. TUI is insured with the policy of IOO,000,000 euro in case of insolvency and of responsibility. TUI signs the contract with an insurance company by which TUI offers the health insurance services and the insurance in case of dismissal. TUI cooperates with DDOR in Serbia. The insurance policy from responsibility is made on IOO,OOO euro while the insolvency policy is made on $\mathrm{I5}, \mathrm{OOO}$ euro. The policy in Serbia is signed only for lawful reasons, but the policy on IOO,000,000 euro actually covers all risks of TUI as well, in Serbia. A tour operator has the right to sell the insurance from more insurance companies, but for the reasons of business, relationships, it decides upon one. Insurance companies pay premiums to travel agencies for sold policies. 


\section{Business ethics and employees}

TUI has a group of employees for internal norms and policy, mandatory for regulating the basic aspects of certain processes or functions, serving as the basis for the application of mechanisms and control. The company has the policy of conduct for employees in the management which regulates the conduct of employees in the management and which, regardless of the applicable legislation, should include all members of the company's management. This regulation regulates, among other things, the conflict of interest, the use of confidential information, the equality of possibility and complaint. Besides this, the people from the management and those persons who, because of their positions, have the access to confidential information, must sign the regulation of internal conduct for the questions related to the market values (TUI documentation, 2OI2).

All employees in this contract on employment have a clause about the prohibition of work for the competition within two years at least from the moment of the termination of the employment in TUI.

Here, the question arises: „Is it ethical that TUI prevents its former employees from continuing their work in the field of their education. This question has had different epilogues in the countries in which TUI operates so that one can come across the instances of filing complaints by the company after the termination of the employment. Moreover, there are the instances when the employees of TUI went to work in the competitive companies and that TUI did not invoke the clause from the contract on employment (TUI documentation, 2009). Certainly it is to TUI's advantage that this company has invested time and effort in its employees, transferred its knowledge to them and has given certain information about its business activities, strategy, market, etc. so that there is a fear of the revelation of all useful information to the competition, and at the expense of TUI.

The internal guide of the TUI company deals with the prevention of money laundering. Among other prohibited activities, the guide emphasizes the activities related to drug trafficking, weapons, terrorism and organized crime. Administrative obligations of inspection, with the aim of revealing and obstructing these practices, arise in the company, all this according to the applicable laws.

The employees are expected to have these characteristics: sincerity, honesty, respect, politeness, helpfulness, obligingness, loyalty and the tendency for team work. The obligations of persons in higher positions and other employees as well are the keeping of business secrets, or the representation of the company's interests. The received information must not be used for obtaining economic benefits. All employees are obliged to represent their company in the best possible way and, also, not to endanger the business of their company in any way.

An employee can solve each disagreement with any participant in the tourist service only directly with the employer and never in the presence of any other participant or third-parties.

The employer is obliged to respect the personality of employees and has a managerial and professional relationship. Any discrimination entails sanctioning. He does not demand from an employee to do work which is contrary to morality, safety of guests and is against rules and laws. He respects all differences of employees, he does not discriminate them in any case.

He respects them and he appreciates them as personalities, allows the freedom of speech and thought, listens to their ideas and suggestions.

Any actions which do not comply with the law are prohibited and each employee is obliged to notify their superiors if he/she finds out that someone does unlawful business. Each embezzlement, evasion or unlawful action is punished with disciplinary proceedings 
and with the removal from office as well. Each disrespect of the contract on employment also entails the sanctions foreseen by the contract on employment.

The representation must not be misused for „drawing cash“ out of the country and daily allowance for business travels must not be shown fictitiously.

If someone of the employees makes an omission unintentionally, the policy of the company states that an individual is not responsible for it, but the whole company takes up responsibility. It must not be allowed in any way that an individual copes with the pressure or is exposed to unneeded stress, because it is necessary that everyone functions as a team before end-users and business partners. It is not allowed to solve problems, existing in the agency, before persons who are the service users or business partners.

The situations, when an unplanned crisis or a huge amount of work appears, are solved in the way that employees have to stay longer at work or to do work at home, and, in return, overtime work is paid in addition, or, when needed, they receive days off. Understanding for private life of workers must exist, but neither must they abuse this tolerance.

\section{The relationship with state institution}

All employees are the representatives of their employer. The employer must obey laws on work, human rights and other laws in the country in which he runs a business. Besides the laws related to human resources, the management is obliged to respect even the laws on traffic, public order and peace, the visa policy.

The law on employment. The Law on Employment in Serbia was changed in July 2OI4, which leads to some changes which have not been yet put into full use, because some modifications of the law are expected in September. Namely, according to the law and rules of business entities, in TUI all employees have the right to social and health insurance. In order to gain this right, the employees must be registered. When receiving new employees, the agreement on volunteering is concluded first, then the contracts for a definite period of employment are signed, most often for three months, which can be prolonged for three months several times. After this, the contract is concluded with the employer for an indefinite period of employment.

Rights and obligations of employees and employers are precisely defined by contracts. If there is a change of work place, the employer is obliged to give the employee a new contract on employment or the annex to the contract of employment. According to the law, the employer is obliged to pay personal income tax, social and health insurance, travel expenses, and hot meal for employees. The employer is also obliged to register employees for full amount of salary, i.e. not to embezzle the personal income tax by the payments of undeclared earnings. If someone of the employees is on pregnancy or maternity leave, the employer does not have the right to fire them.

The company is considered, responsible in the relationship with the state institutions, to insist on:

I. The cooperation with them in the search for general social interests, in the sense of giving essential feedback to the state institutions, so as to coordinate regulations with the situation on the terrain;

2. Not accepting, nor offering the bribe in money or in kind;

3. Avoiding taking a political position on behalf of the company;

4. Directing public affairs to a person with an appropriate level of responsibility in the company. 
If the tourist, financial or some other inspection comes, employees are obliged to provide them with the insight into the whole documentation, and, also, to answer them unambiguously. According to the function which they perform, employees are obliged to give them all relevant information related to the business activities of the company. Moreover, they are obliged to abide by the law on fiscal and monetary policy. According to the Law on Tourism, it is precisely stated that the tourist arrangements are fiscalized while the airplane tickets are not fiscalized. It is also important to mention whether the agency is in the value added tax system or is not in the stated system. Each receipt must contain the stated article of the law if a certain service is a subject to VAT or not, and, also, the appearance of the receipt which a tour operators issues to an end-user or intermediaries. The estimates and bills must contain the exact name of the company full name and address; personal identification number and TIN (tax identification number); number of licence; current account of the agency; articles of the laws related to the service; if the bill is shown in euro, the exchange rate by which the payment will be made is in Serbian Dinar (RSD); detailed information about the services which have been bought (TUI documentation, 2OI4).

\section{The relationship with media}

The company makes an effort to be open for all kinds of media, because it is in general interest both for the company and the public. In the company, there are the employees responsible for public relations and their duties are:

- To respond to the posed questions as fast as possible;

- To protect the image and reputation of the company, its strategies and its material and non-material property;

- To avoid stating personal opinions or passing the official opinion of the company on a particular issue;

- Do not state unverified information, nor the plans of the company for which it is not certain yet if will be fulfilled;

- Do not state their opinion on the questions for which the company does not have the official opinion, nor state their opinions on the questions which do not have anything in common with the company's business activities, like political, religious, national questions;

- Avoid making statements on topics which are not known enough, or are not in the description of a job of a person stating that information, in this case, it is necessary to consult the corresponding company officials;

- Make all statements objectively and impartially (TUI documentation, 2OIO).

\section{Sustainable development and social responsibility}

Through the attendance at various forums and events, TUI aims at strengthening its links and relationships with civil society, multilateral organizations, public administrations and significant persons and leaders of public opinion. In 2OI2, the company has an institutional presence at organizations related to tourism, business entities, management organizations, sustainability, social responsibility and academic world. TUI believes that the business according to the principles of sustainable is the only way for tourism to continue its development and to remain as one of the main engines powering the economy of many countries. 
The tourism sector is especially sensitive to the environment in which it develops. Extreme weather, in other words, climate changes such as hurricanes and floods, drought and the lack of snow, influence the development of tourist activities. The loss of cultural identity can lead to the reduction of its attractiveness, disappearance of uniqueness which makes it special. Besides this, the existence of poverty in the communities in which the company operates is the reality. TUI believes that its obligation which it has to accomplish is before is to improve these situations before its employees, clients and the society in general.

The company tends to lead the firm through sustainable business.

The protection of the nature and cultural heritage. First of all, TUI is conscious of the responsibility which such a great company has towards its clients, but both to the nature and the society. It makes an effort for continuous improvement of their systems for measuring the influence of business on the environment both at the local and global level, committing itself to introducing the management for the environment into their everyday work. TUI tries to reduce the influence of its activities and to contribute to the preservation of biodiversity of tourist destinations through the landscape integration and the respect of their flora and fauna. TUI strives to take care of saving the energy consumption and water and even the reduction of gas emission, always searching for the efficacy and suppression of these in the consumption of natural resources and responsibly managing its waste and air pollution. However, the specific measures from this problem area have not been undertaken yet in TUI in Serbia.

One of the obligations of TUI is even the reduction of social differences and the reduction of poverty through the possibilities for mutual economic growth. As a company, it is especially sensitive to social groups such as older people, people with disabilities, children (the future bearers of its heritage).

The company wants to share its devotion to the sustainable development and social responsibility with its main interest groups. These are the employees, suppliers, clients, shareholders and owners of its hotels, seeking from them to adopt the policy of continuous improvement in relation to the integration of a criterion of the sustainable development in its business activities, such as the negative effect on the environment and the economic growth development of destinations. Devotion to the sustainable development is the need that future generations can enjoy natural and cultural heritage in the same way as we can nowadays and not make immediate profits due to the mass tourism which will have irreversible consequences both for tourism and the society in general. The company endeavours to act responsibly towards the society and to give the example in this way to business partners and individuals to follow it in business based on the sustainable development, respect of all differences, development of local cultures, traditions and values, with a special reference to the poorest and children as the special category. Therefore, the obligations the company towards the society are:

- Help in the action for specially endangered groups, especially emphasizing all that can infringe children's rights;

- Help in the actions for uprooting the exploitation of children in undeveloped countries like India, Thailand, Cambodia...;

- The fight for the equality between the sexes, for the rights of people with disabilities, the actions oriented on the suppression of all kinds of discrimination;

- Stimulating the development and maintaining local cultures and customs (e.g. investing in the increase of the living standard of local population, development of consciousness about the needs of education and health protection. 
The company insists on raising the awareness of the trade and exploitation of children, especially taking into account the fact that it directs many passengers to the countries of Southeast Asia, especially to Thailand, where a high level of children sexual exploitation is. The company appeals to its passengers that these offences are, first of all, morally unacceptable and even strictly prohibited by law. TUI has participated in the projects, organized by non-governmental organizations so that as many people can be informed about this problem. On the other hand, TUI participates in the companies promoting children's rights and appeals not to exploit children who are not capable of work. The problem of this type happens most often in China, Taiwan, Cambodia, and Vietnam where children have to work in factories for 12 or more hours due to the low standard of living and they receive only several dollars per month. As one of the ways to express disapproval of children's maltreatment, the company has introduced a clause in the contracts with business partners stating that the contract is terminated in case that they hire children to work in their production processes.

\section{Conclusion}

One can conclude from the research that TUI has a complex business ethical codex in order to cover different spheres of business activities. However, several disputable examples have been stated depending on the angle from which the problem is viewed, meaning that there is a chance of misusing ethical codex and interpreting it in the way suitable to some parties. One can also conclude that TUI establishes its business on the concept of cooperative social responsibility, because the company is dedicated even to the protection of the environment, improvement of life of the local population, preservation of their customs, cultures and traditions. Furthermore, one can notice the support for the most sensitive categories of population such as children, pregnant women, and people with disabilities.

The system of business ethics should be ingrained in all companies, regardless of their size and the possibility to force the implementation of established ethical norms to their employees and business partners as well.

This paper could be useful for Serbian tour operators and in general for Serbian tourism policy creators in order to improve tour operators' business ethics and their management in general, based on TUI experience and practice.

\section{References}

Bogdanovic, M. (2008). Factors of ethical influence on business system. Papers of the Institute for Scientific Work - Varazdin, 19, 295-318.

Connock, S. and Johns, T. (1995). Ethical leadership. London: IPD.

D'Amore, L. J. (I993). A code of ethics and guidelines for socially and environmentally responsible tourism. Journal of Travel Research, 3I(3), 64-66.

Dornier, R., Cothias, V. and Loussaief, L. (2OII). The application of collective ethics charters The case of French adventure tour-operators. International Business Research, 4(I), I33-I44. Dragin, A. S. (2OII). Tourism and business ethics, material from lectures, University of Novi Sad, Faculty of Sciences, Department of Geography, Tourism and Hotel Management, Novi Sad. 
Dunfee, T. W. and Black, B. M. (1996). Ethical issues confronting travel agents. Journal of Business Ethics, I5, 2O7-2I.

Fennell, D. and Malloy, D.C. (2007). Codes of ethics in tourism: practice, theory, synthesis. Clevedon: Channel View Publications.

Jovicic, A., Pivac, T. and Dragin, A. (2OII). Ethical conduct of employees in tourist organizations in Novi Sad (Serbia). International Scientific Journal Turizam, I5(4), I35-I47.

Lewis, P. V. (1985). Defining "business ethics": Like nailing jello to a wall. Journal of Business ethics, 4(5), 377-383.

Malloy, D. C. and Fennell, D. A. (1998). Codes of ethics and tourism: An exploratory content analysis. Tourism Management, I9(5), 453-46I.

Minciu, R. (2008). Codul global de etică în turism - Stadiul de implementare (Aspects of the implementation degree of the World code of ethics in tourism). Amfiteatru Economic, 23, 66-7I.

Miskovic, I. (2OI2). Ethics in providing tourism services by travel agents in Serbia. International Scientific Journal Turizam, I6(I), 2O-28.

Orme, G. and Ashton, C. (2OO3). Ethics - a foundation competency. Industrial and Commercial Training, 35(5), I84 - I9O.

Ristić, D. (2004). Basics of management. Faculty for Management, Novi Sad (In Serbian).

Simat, K. and Dragin, A. (2OI2). Business ethics - An element of successful business of travel agencies. Researchers Review of the Department of Geography, Tourism and Hotel Management in Novi Sad, 4I, 297-309.

Simat, K., Dragin, A. and Dragicevic, V. (2OI2). The institutionalization of business ethics of travel agencies in Serbia. International Scientific Journal Turizam, I6(3), II3-I23.

Stevens, B. (2OOI). Hospitality ethics: responses from human resource directors and students to seven ethical scenarios. Journal of Business Ethics, 3O, 233-242.

Trevino, L. K. and Nelson, K. (I999). Managing business ethics: Straight talk about how to do it right. New York: John Wiley \& Sons Inc.

TUI documentation 2009 - 2013

Šuleić, M. (2OI4). Business ethics and tour operator TUI, master thesis. University of Novi Sad Faculty of Sciences, Department of Geography, Tourism and Hotel Management (In Serbian).

http://de.statista.com/statistik/daten/studie/30079/umfrage/umsatz-der-tui-ag/ www.tui-group.com/en/company/profile

www.tui-reisecenter.rs 